\title{
THE USE OF INFLAMMATORY MARKERS FOR IDENTIFICATION OF SOME DISEASES IN BUFFALOES
}

\author{
EL-SANGARY, F. H., MAGDA M. MOHAMED, AMINA E. FARIS AND \\ MAGDA N. ABDEL-HAMIED
}

Animal Health Research Institute, ARC, Ministry of Agriculture, Dokki, Giza

(Manuscript received 4 February 2009)

\begin{abstract}
This study aimed to evaluate the clinical diagnostic value of some acute phase proteins (Haptoglobin, C- reactive proteins, fibrinogen) as a markers of infection and inflammation in buffaloes affected with mastitis and with pneumonia. twenty buffaloes (4-6 years) suffering from acute mastitis and 20 buffalo-calves (3 - 6 months) suffered from pneumonia were used in this study. The apparently healthy groups included 10 buffaloes and 10 buffalocalves, served as control. The animals belonged to some private farms in Sharkia Governorate. Milk samples were collected from mastitic buffaloes, and nasopharyngeal swabs were collected from pneumonic buffalo-calves for bacteriological examination. Blood samples were collected also for determination of serum total proteins, albumin, CRP, $\mathrm{Hp}$ and plasma $\mathrm{Fb}$. The obtained results revealed a significant increase in $\mathrm{Hp}, \mathrm{CRP}$, and $\mathrm{Fb}$ levels in diseased animals than healthy ones. Also, an increase in serum total proteins accompanied with a decrease of serum albumin in diseased animals was observed.

From this study, it can be concluded that, the inflammatory markers ( $\mathrm{Hp}, \mathrm{CRP}, \mathrm{Fb})$ may act as an early indicators of infection and inflammation in some diseases in buffaloes.
\end{abstract}

\section{INTRODUCTION}

The acute phase proteins (APP) are a group of blood proteins that change in their concentration in animals subjected to external or internal challenges, such as infection, inflammation, surgical trauma or stress. The APP are considered to be nonspecific innate immune component involved in the restoration of homeostasis and the restraint of microbial growth before animals develop acquired immunity to a challenge. The circulating concentration of the APP is related to the severity of the disorder and the extent of tissue damage in the affected animal; therefore, quantification of their concentration can provide a diagnostic and a prognostic information. Serum APP show species - related difference on their response to stimuli, Haptoglobin, Fibrinogen, and C- reactive protein are major APP in ruminants, but not in other species. Haptoglobin, Fibrinogen, and C- reactive protein are positive APP; they are glyco- proteins synthesized mainly by hepatocytes upon stimulation by pro- inflammatory cytokines and released into the blood stream. Inflammation, infection or tissue injury will trigger 
cytokine release by defence oriented cells, thereby, inducing APP synthesis (Murata et al., 2004).

Haptoglobin ( $\mathrm{Hp}$ ) is an alpha - globulin constituent, binds free haemoglobin, which is released either by haemolysis or during erythrocyte turn- over. It is a major APP in ruminants, its circulating level is negligible in healthy animals, but increases over 100 -fold on immune stimulation in response to infection and tissue injury. Many studies have indicated the significance of $\mathrm{Hp}$ as a clinically useful parameter for measuring the occurrence and severity of inflammatory responses in cattle infected with mastitis (Ohtsuka et al., 2001), and also with pneumonia (Heegaard et al., 2000).

Fibrinogen $(\mathrm{Fb})$ is involved in homeostasis, providing a substrate for fibrin formation, and in tissue repair, providing a matrix for the migration of inflammatory related cells. It is used in cattle as a reliable indicator of the presence of inflammation, bacterial infection or surgical trauma (Thomas, 2000).

C- reactive protein (CRP) has been demonstrated in ruminants. It plays important roles in protection against infection, clearance of damaged tissue, prevention of auto immunization and regulation of the inflammatory response (Mold et al., 2002).

The aim of this work is to evaluate the clinical diagnostic value of acute phase proteins $(\mathrm{Hp}, \mathrm{Fb}, \mathrm{CRP})$ as a marker of infection and inflammation in buffaloes affected with mastitis and pneumonia.

\section{MATERIALS AND METHODS}

\section{I- Animals}

Thirty dairy buffaloes (3-5 years), and other thirty buffalo-calves (3-6 months), belonging to some private farms in Sharkia Governorate, were used in this study.

A- Twenty dairy buffaloes showed systemic and local clinical signs of acute mastitis (Body temperature, rumen motility, appetite, udder swelling and abnormal milk secretion). The other ten buffaloes were apparently clinically healthy and served as a control group.

B- Twenty buffalo-calves showed signs of pneumonia (fever $41^{\circ} \mathrm{C}$, nasal discharge, cough, dyspenia and rapid respiration). The other ten calves showed no signs of illness and served as a control group.

\section{II- samples and adopted methods}

\section{1- Milk samples}

Procedures for collection and diagnosis of milk samples were performed as described by Brown et al., (1981). The samples were positive for clinical mastitis, based on any observable signs in the udder and/or milk and delivered for 
bacteriological examination. California mastitis test was applied on milk samples of each quarter of udder of clinically healthy individual buffalo.

\section{2- Nasopharyngeal swabs}

These were collected from buffalo-calves showing respiratory signs for bacteriological examination. The collected samples were examined bacteriologicaly according to Brown et al. (1981).

\section{3- Blood samples}

Two blood samples were collected from each animal, through jugular vein puncture, the first one was with Heparin as anticoagulant for measuring plasma fibrinogen level. The second blood sample was without anticoagulant to obtain clear, non-haemolysed sera. Plasma fibrinogen level, serum C-reactive protein, Albumin and total serum protein levels were determined according to the methods reported by Kits of Biosystems S.A. (Spain) \& Bio-Med Diagnostics (Egypt). Serum haptoglobin level was determined by means of sodium dodecyl sulphat-polyacrylamide gel electrophoresis (SDS-PAGE) according to Yoshino et al., (1992).

Statistical analysis of the obtained data were performed according to Snedecor and Cochran (1984).

\section{RESULTS AND DISCUSSION}

The results of this study were tabulated in Tables 1,2,3 and 4. The bacteriological examinations of milk samples (Table 1), revealed that the main isolates were Staphylococcus aureus (30\%), E-coli (25\%), Streptococcus agalactia (20\%), Corynbacterium pyogenes (15\%), and Pseudomonas aerugenosa (10\%). These findings were nearly similar to those previously mentioned by Seddek (1996). The bacteriological examinations of nasopharyngeal swabs (Table 2) revealed that Pasteurella multocida, Mannheimia haemolytica type A, E- coli and Staphylococcus aureus are the most causative agents at percentages 30\%, 20\%, 20\% and $15 \%$, respectively. These results were nearly similar to those previously recorded by Roberson et al. (1994).

Regarding the biochemical analysis of serum and plasma, the results are tabulated in Tables 3\&4. The levels of APP ( $\mathrm{Hp}, \mathrm{CRP}, \mathrm{Fb}$ ) are very low in healthy dairy buffaloes and buffalo-calves (control group). These agreed with those previously reported in cattle by Marimatsu et al. (1992), who mentioned that normal cattle have $\mathrm{Hp}$ concentration less than $0.1 \mathrm{~g} /$ litre, threshold value above $0.4 \mathrm{~g} /$ litre, considers presence of bacterial infection. $\mathrm{Hp}$ is a haemoglobin binding protein and is considered the main APP in cattle, its value of $10 \mathrm{mg} / \mathrm{ml}$ has been considered to be within the physiological limits. 
Recently, Gronlund et al. (2005) reported that $\mathrm{Hp}$ is present in normal bovine sera at a level of $100 \mu \mathrm{g} / \mathrm{ml}$ or less, and its level increases as much as 10 fold in response to a number of bacterial infections, and its concentration below the detection limit was considered as good indicator of healthy udder quarters.

On the other hand, the mastitic dairy buffaloes and pneumonic calves, showed a significant increase in the concentration of Hp, CRP and fibrinogen. These results agreed with those recorded by Eckersall and Conner (1988) who stated that the acute phase proteins are good indicators of acute infection, and reported that $\mathrm{Hp}$ was a prominent acute phase reactant in cows with mastitis, where besides the clinical signs of the bacterial counts in milk, the level of $\mathrm{Hp}$ is an important marker for inflammation. Also, Wittum et al. (1996) mentioned that $\mathrm{Hp}$ is suitable for use as an inflammatory marker in mastitis, and reported mean serum $\mathrm{Hp}$ concentration of $69 \mathrm{mg} / \mathrm{dl}$ for 26 cows affected with clinical mastitis.

Regarding APP response to clinical respiratory tract disease, little informations are available. Wittum et al. (1996) reported mean serum $\mathrm{Hp}$ value of $67 \mathrm{mg} / \mathrm{dl}$ in 60 feedlot calves with clinical respiratory tract diseases. Lastly, Fagliari et al. (2003) found significant increase in serum $\mathrm{Hp}$ concentration in calves with pneumonic pasteurellosis, compared with control calves. The mean serum Hp concentration peaked at $100 \mathrm{mg} / \mathrm{dl}$; this increase is due to the inflammation and lung damage.

Regarding the serum CRP levels in diseased animals in this study, there was a significant increase in its levels in these animals than in the healthy ones. These results coincide with those reported by Lee et al. (2003), who recorded that CRP increases rapidly in the sera of most animals suffering from acute inflammation caused by infection or tissue injury, and may be effectively used to determine and control udder illness in cows, where its level was the highest during naturally occurring infections, such as mastitis and other tissue inflammation, and this level is a marker or tool for evaluating the health status of a herd.

Concerning the plasma fibrinogen levels in mastitic buffaloes and pneumonic calves in this study, there was a significant increase in their levels in diseased animals than in healthy ones. Similar results were obtained by Eckersall and Conner (1988), who found an increase in mean plasma fibrinogen in sick cows than in normal ones, and attributed this increase to inflammation and tissue destruction, and reported that plasma fibrinogen levels correlated with the severity of the disease, levels of $1.000 \mathrm{mg}$ per $100 \mathrm{ml}$ or more reflected a poor to bad prognosis.

Concerning serum albumin and serum total proteins levels in this study, there was a significant drop in serum albumin, accompanied by significant increase in serum total protein in diseased animals. Similar findings were reported by Thomas (2000), 
who mentioned that lower albumin level concomitant with the higher total protein level was characteristic for inflammatory process. Eckersall and Conner (1988) reported that the acute phase response leads to increased serum levels of a number of positive acute phase proteins and to a concomitant decrease in negative acute phase proteins such as albumin. Recently, Amina and Selim (2007) attributed this decrease in serum albumin to the bacterial toxins which may affect the hepatic parenchyma resulting in failure of liver to synthesize albumin.

\section{CONCLUSION}

The acute phase proteins (APP) produced during the early inflammatory response, represent a potentially useful systemic marker of bacterial infection and other inflammatory diseases. Their values in conjunction with other common measures might prove to be more useful. They provide a method of determining the true health status, and as a diagnostic tool for some diseases in animals. The application of these APP to veterinary diagnosis seems promising, but needs further investigations.

\section{ACKNOWLEDGMENT}

The authors thank Dr. Hany Hassan, Department of immunology, Animal Reproduction Research Institute, and Dr. Mokhtar Selim, Department of bacteriology, Animal Health Research Institute, Zagazig, for their technical assistance. 
Table 1. Results of bacteriological examination of milk from mastitic buffaloes.

\begin{tabular}{|c|c|c|c|c|c|c|}
\hline No. of & \multicolumn{6}{|c|}{ Isolated Bacteria } \\
\hline \multirow[t]{7}{*}{20} & \multicolumn{3}{|c|}{$\begin{array}{l}\text { Single isolates } \\
(\mathrm{n}=12,60 \%)\end{array}$} & \multicolumn{3}{|c|}{$\begin{array}{l}\text { Mixed isolated } \\
(\mathrm{n}=8,40 \%)\end{array}$} \\
\hline & & No. & $\%$ & & No. & $\%$ \\
\hline & Staphylococcus aureus. & 4 & 35 & \multirow{2}{*}{$\begin{array}{l}\text { Staphylococcus aureus } \\
\text { (2) + Streptococcus } \\
\text { agalacita (1) }\end{array}$} & \multirow[t]{2}{*}{3} & \multirow[t]{2}{*}{38} \\
\hline & Streptococcus agalacita & 3 & 25 & & & \\
\hline & $\begin{array}{l}\text { Corynbacterium } \\
\text { Pyogenes }\end{array}$ & 1 & 8 & \multirow{3}{*}{$\begin{array}{l}\text { Corynbacterium } \\
\text { pyogenes (2) + E- coli } \\
\text { (3) }\end{array}$} & \multirow[t]{3}{*}{5} & \multirow[t]{3}{*}{62} \\
\hline & E-coli & 2 & 16 & & & \\
\hline & $\begin{array}{l}\text { Pseudomonas } \\
\text { aeruginosa }\end{array}$ & 2 & 16 & & & \\
\hline
\end{tabular}

Table 2. Results of bacteriological examination of nasopharyngeal swabs.

\begin{tabular}{|c|c|c|c|c|c|c|}
\hline No. of & \multicolumn{6}{|c|}{ Isolated Bacteria } \\
\hline \multirow[t]{6}{*}{20} & \multicolumn{3}{|c|}{$\begin{array}{l}\text { Single isolates } \\
(\mathrm{n}=7,35 \%)\end{array}$} & \multicolumn{3}{|c|}{$\begin{array}{l}\text { Mixed isolated } \\
(n=13,65 \%)\end{array}$} \\
\hline & & No. & $\%$ & & No. & $\%$ \\
\hline & $\begin{array}{l}\text { Pasteurella } \\
\text { multocida }\end{array}$ & 2 & 29 & $\begin{array}{c}\text { P. multocida }(4)+ \\
\text { Mannheimia } \\
\text { haemolytica type } A(2)\end{array}$ & 6 & 46 \\
\hline & $\begin{array}{l}\text { Mannheimia } \\
\text { haemolytica type } A\end{array}$ & 2 & 29 & \multirow[t]{2}{*}{$\begin{array}{l}\text { Staphylococcus aureus } \\
(2)+E \text {-coli (1). }\end{array}$} & \multirow[t]{2}{*}{3} & \multirow[t]{2}{*}{23} \\
\hline & Staphylococcus aureus & 1 & 13 & & & \\
\hline & E-coli & 2 & 29 & $\begin{array}{l}\text { Streptococcus species } \\
(3)+E \text {-coli }(1)\end{array}$ & 4 & 31 \\
\hline
\end{tabular}


Table 3. Mean values of serum total protein, alumin, haptoglobin, C-reactive protein, and plasma fibrinogen in both apparently healthy and mastitic buffaloes.

\begin{tabular}{|c|c|c|}
\hline \multirow{2}{*}{ Parameters } & \multicolumn{2}{|c|}{ Buffalo } \\
\hline & Apparently healthy & Mastitic \\
\hline Total protein $(\mathrm{gm} / \mathrm{dl})$ & $7.45 \pm 0.22$ & $8.81 \pm 0.51^{\times}$ \\
\hline Albumin (gm/dl) & $3.2 \pm 0.41$ & $2.14 \pm 0.13^{\times}$ \\
\hline Haptoglobin (gm/dl) & $0.286 \pm 0.069$ & $1.24 \pm 0.23^{x \times x}$ \\
\hline C- reactive protein $(\mathrm{mg} / \mathrm{L})$ & $5.4 \pm 0.85$ & $14.6 \pm 2.1^{\times \times x}$ \\
\hline Plasma Fibrinogen (mg/dl) & $455 \pm 38$ & $721 \pm 82^{\times x}$ \\
\hline
\end{tabular}

Table 4. Mean values serum total protein, albumin, haptoglobin, C-reactive protein and plasma fibrinogen in both apparently healthy and pneumonic calves.

\begin{tabular}{|c|c|c|}
\hline \multirow{2}{*}{ Parameters } & \multicolumn{2}{|c|}{ Buffalo-calves } \\
\cline { 2 - 3 } & Apparently healthy & Pneumonic calves \\
\hline Total protein $(\mathrm{gm} / \mathrm{dl})$ & $7.03 \pm 0.29$ & $8.11 \pm 0.13^{\times \times}$ \\
\hline Albumin $(\mathrm{gm} / \mathrm{dl})$ & $3.4 \pm 0.16$ & $2.3 \pm 0.41^{\times}$ \\
\hline Haptoglobin $(\mathrm{gm} / \mathrm{dl})$ & $0.241 \pm 0.035$ & $1.11 \pm 0.16^{\times \times \times}$ \\
\hline C- reactive protein $(\mathrm{mg} / \mathrm{L})$ & $4.21 \pm 0.32$ & $10.48 \pm 1.0^{\times \times \times}$ \\
\hline Plasma Fibrinogen $(\mathrm{mg} / \mathrm{dl})$ & $380 \pm 25$ & $641 \pm 71^{\times \times}$ \\
\hline
\end{tabular}

$x$ Significant at $(P<0.05)$

$x x$ Highly Significant at $(P<0.01)$

$x x x$ very Significant at $(P<0.001)$ 


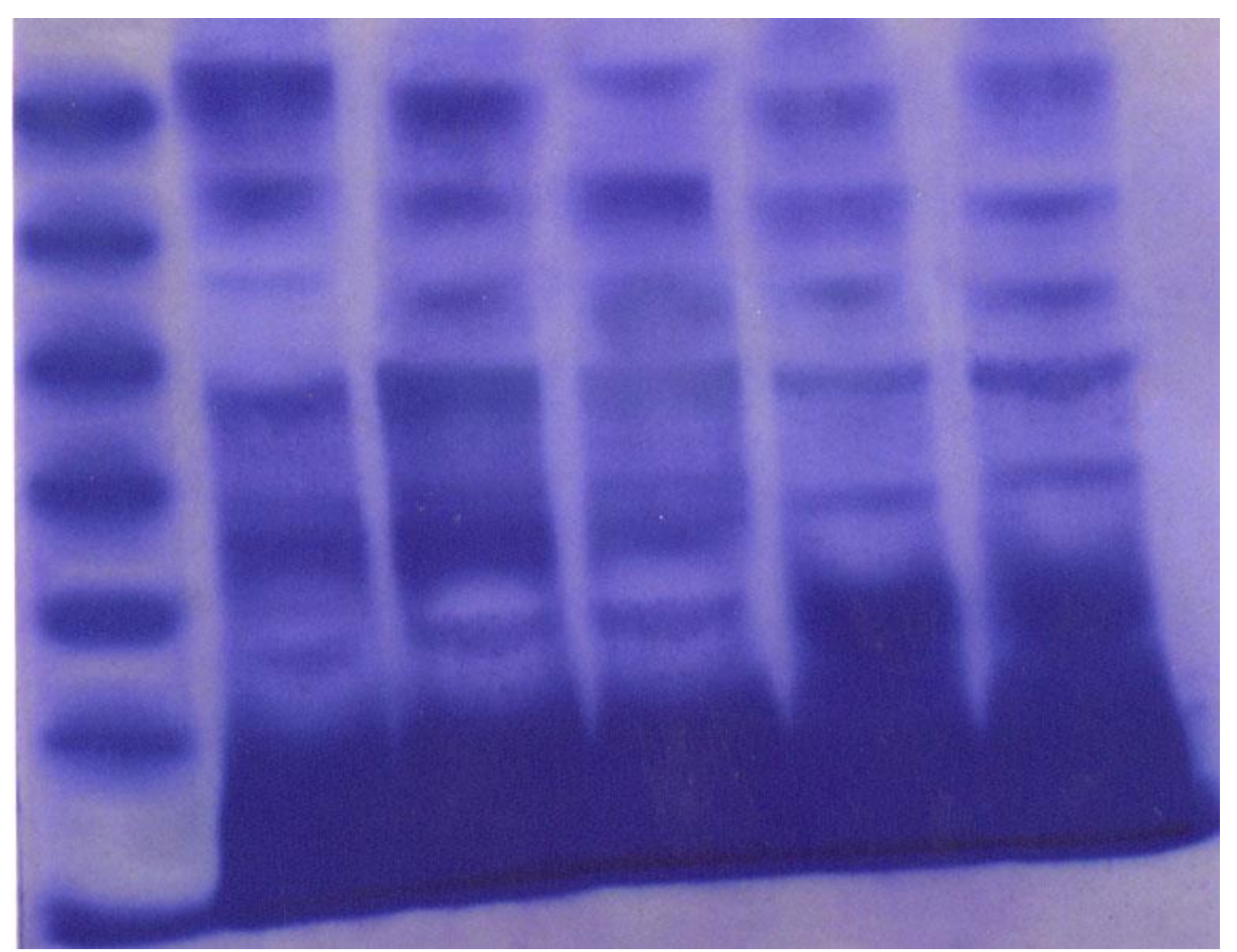

Fig. 1. Sodium dodecyl sulfate-polyacrylamide gel electrophoretogram (SDS-PAGE).

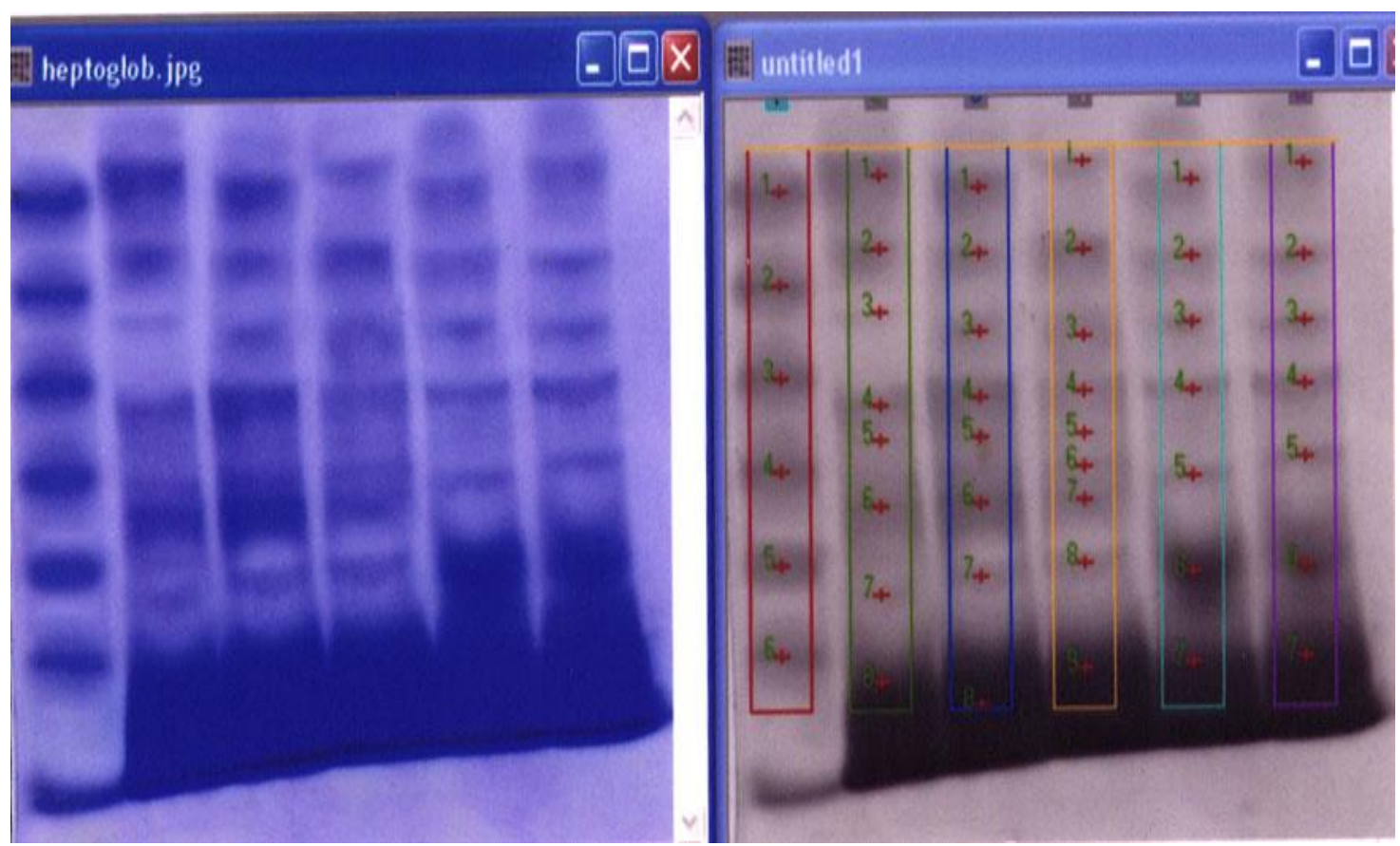

The molecular weight (MW) of HP was estimated to be approximately 100.000K.D. 


\section{REFERENCES}

1. Amina E. Faris and M. A. Selim. 2007. Some Biochemical, haematological and bacteriological studies associating bloody milk in buffalow and trials for treatment. Zag. Vet. J., 35(3) : $95-103$.

2. Brown, R. W., D. A. Barnum, D. E. Jasper, J. S. Mcdonald and W. Schultz. 1981. Microbiological procedures for the diagnosis of bovine mastitis. $2^{\text {nd }}$ ed. National mastitis council, Arlington, VA. PP. 10-15.

3. Eckersall, P. D. and J. G. Conner. 1988. Bovine and canine acute phase proteins. Vet. Res. Commun., $12: 169-178$.

4. Fagliari, J. J., D. J. Weiss and D. Mclenanhan. 2003. Serum protein concentrations in calves with experimentally induced pneumonic pasteurellosis. Arq. Bras. Med. Vet. zootec., 55, 4.

5. Gronlund V., C. Hallen Sandgren and K. Person Waller. 2005. Haptoglobin and serum amyloid $A$ in milk from dairy cows with chronic subclinical mastitis. Vet. Res., 36 (2) : $191-198$.

6. Heegaard, P. M., D.L. Godson, M. J. Toussaint, K. Toornehooj and L.E. Larsen. 2000. The acute phase response of haptoglobin and serum amyloid A (SAA) in cattle undergoing experimental infection with bovine respiratory syncytial virus. Vet. Immun., $77: 151-159$.

7. Lee W. C., H. C. Hsiao and W. U. Lin. 2003. Serum C- reactive protein in dairy herds. Can. J. Vet. Res., 67 (2) : $102-107$.

8. Marimatsu, M., M. Sarikaputi, B. Syuto and M. Saito. 1992. Bovine Haptoglobin : Single radial immunodiffusion assay of its polymeric forms and dramatic rise in acute-phase sera. Vet. Immun., $33: 365-372$.

9. Mold, C., W. Rodriquez and B. Rodic - Polic. 2002. C- reactive protein mediates protection from lipopolysaccharide through interactions with Fc- gamma. J. immun., 169 : $7019-7025$.

10. Murata, H., N. Shimada and M. Yoshioka. 2004. Current research on acute phase proteins in veterinary diagnosis : an overview. The Vet. J., $168: 28-40$.

11. Ohtsuka, H., K. Kudo, K. Mari, F. Nagai, A. Hatsugaya. 2001. Acute phase response in naturally occurring coliform mastitis. J. Vet. Med. Sc., $63: 673-678$. 
12. Roberson, J. R., L. K. Fox, D. D. Hancock, J. M. Gay and T.B. Besser. 1994. Effect of staphylococcus aureus isolated from various sites on dairy farms. J. Dairy Sc., 77 (11) : $3354-3364$.

13. Seddek, S. R. 1996. Bovine mastitis : age, causes and control in Assiut Governorate. Assiut Vet. Med. J., 36 (71) : $149-162$.

14. Snedecor, G. W. and W.G. Cochran. 1984. Statistical methods. Iowa state, University press, Iowa, U.S.A.

15. Thomas, J. S. 2000. Overview of plasma proteins. In : Feldman, B.F., Zinkl, J.G., Jain, N.C. (Eds), Schalm's Vet. Hematology, Fifth Ed., PP. $891-898$.

16. Wittum, T.E., C. R. Young, L.H. Stanker, D. D. Criffin. 1996. Haptoglobin response to clinical respiratory tract disease in feedlot cattle. Am. J. Vet. Res., $57: 646$ 649.

17. Yoshino, K., N. Katoh, K. Takahasi, and A. Yuasa. 1992. Purification of a protein from serum of cows with hepatic lipidosis, and identification of the protein as haptoglobin. Am. J. Vet. Res., 53 : 951 - 956. 


\section{إستخدام دلالات الإلتهاب للتعريف ببعض الأمراض في الجاموس}

فؤاد حامد السنجري، ماجدة ممدوح محد، أمينة السيد فارس، ماجدة نعمت عبد الحميد

$$
\text { معهد بحوث صحة الحيوان - مركز البحوث الزراعية - وزارة الزراعة - الدقي - جيزة }
$$

haptoglobin, C- ) استهدفت هذه الدراسة معرفة مدى إمكانية استخدام بعض دلالات الألتهاب



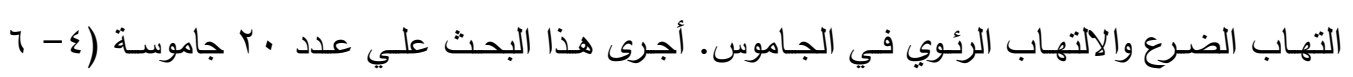

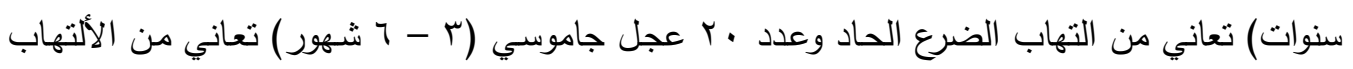


العجول الأصحاء ظاهريا، وذلك من بعض المزارع الخاصة بمحافظة الثرقية. تم في هذه الدراسة إجراء أركاء



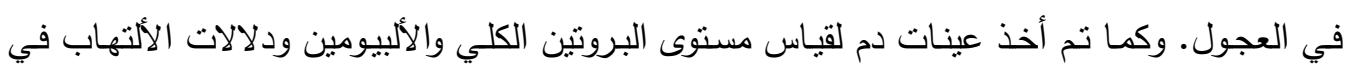

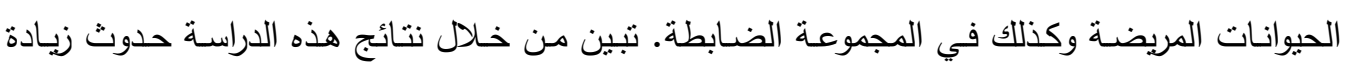

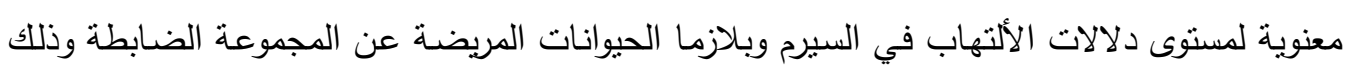
كرد فعل أولي لحدوث الألتهاب والعدوى المرضية بها - كما تبين حدوث نقص في مستوى الأنس الألبيومين وزيادة في مستوى البروتين الكلي في الحيوانات المريضة عن المجموعة الضابطة.

نستخلص من هذه الدراسـة أهمية قياس دلالات الألتهاب في بعض الحالات المرضية كونها


ومؤشراً للحالة الصحية العامة للحيوان. 